\title{
Edukasi Pembukuan Kas Kepada Usaha Kecil Telur Asin di Kelurahan Genuksari Kecamatan Genuk
}

\author{
Emaya Kurniawati ${ }^{1}$, Sri Yuni Widowati ${ }^{2}$, Aprih Santoso ${ }^{3 *}$ \\ 1,2,3 Jurusan Manajemen, Fakultas Ekonomi, Universitas Semarang, \\ Semarang 50196, Jawa Tengah, Indonesia. \\ *Penulis korespondensi: Aprih Santoso, Jurusan Manajemen FE USM \\ Email: aprihsantoso@usm.ac.id
}

\begin{abstract}
ABSTRAK
Usaha Kecil Telur Asin di Kelurahan Genuksari Kecamatan Genuk berjumlah 29 pelaku usaha. Pelaku usaha kecil telur asin selama ini dalam menjalankan usahanya masih menghadapi masalah yaitu belum melakukan pembuatan pembukuan kas. Tujuan Tim melakukan PKM adalah untuk menyelesaikan permasalahan yang ada pada pelaku usaha telur asin yaitu dengan melakukan edukasi pembukuan kas. Metode PKM yang dilaksanakan berupa penyuluhan pembukuan kas kepada pelaku usaha kecil telur asin di Kelurahan Genuksari Kecamatan Genuk. Disamping penyuluhan juga dilakukan kegiatan contoh kasus untuk memotivasi para pelaku usaha kecil telur asin lebih paham tentang pembukuan kas. Capaian kegiatan PKM atas pelaksanaan edukasi pembukan kas adalah tersusunnya pembukuan kas yang dapat menghasilkan informasi keuangan berupa laporan arus kas yang bermanfaat untuk pendukung kinerja Usaha Kecil Telur Asin di Kelurahan Genuksari Kecamatan Genuk Kota Semarang.
\end{abstract}

Kata kunci : Pembukuan; Kas; Keuangan

ABSTRACT

Salted Egg Small Business in Genuksari Subdistrict, Genuk Subdistrict, there are 29 business operators. The small-scale salted egg business performer in his business still faces the problem of not yet making cash bookkeeping. The objective of the Team conducting PKM is to solve problems with the salted egg business actors by conducting cash bookkeeping education. The PKM method is carried out in the form of counseling of cash books for small-scale salted egg entrepreneurs in the Genuksari Village, Genuk District. Besides counseling, case study activities were also carried out to motivate small-scale salted egg small businesses to better understand cash books. The achievement of PKM activities on the implementation of cash accounting education is the compilation of cash books that can produce financial information in the form of cash flow reports that are useful for supporting the performance of the Salted Egg Small Business in Genuksari Village, Genuk District, Semarang City.

Keywords: Bookkeeping, Cash, Financial 


\section{PENDAHULUAN}

\section{Analisis Situasi}

Genuksari merupakan sebuah kelurahan di wilayah kecamatan Genuk, Kota Semarang, Provinsi Jawa Tengah. Nama Genuksari berarti gentong yang indah/bagus. Nama tersebut diberikan oleh Ki Ageng Pandanaran saat menemukan gentong di wilayah ini. Luas Wilayah Kelurahan Genuksari seluas $\pm 244,5$ ha. Adapun batas-batas wilayahnya, yaitu: sebelah barat berbatasan dengan Kel Gebangsari; sebelah utara berbatasan dengan Kel Trimulyo dan sebelah timur berbatasan dengan Kel. Banjardowo; serta sebelah selatan berbatasan dengan Kel. Bangetayu Kulon

Jumlah penduduk di Kelurahan Genuksari sampai dengan bulan Januari 2019 sebanyak 17.456 jiwa, dengan perincian : Jumlah penduduk laki-laki sebanyak 8.774 jiwa dan jumlah penduduk perempuan sebanyak 8.691 jiwa. Adapun untuk jumlah RT sebanyak 78 RT dan untuk jumlah RW sebanyak 11 RW.

Usaha Mikro dan Kecil (UMK) merupakan kegiatan usaha yang mampu memperluas lapangan kerja, memberikan pelayanan ekonomi secara luas kepada masyarakat, berperan dalam proses pemerataan dan peningkatan pendapatan masyarakat, mendorong pertumbuhan ekonomi, dan berperan dalam mewujudkan stabilitas nasional (Iman dan Adi, 2009). Tujuan usaha mikro menurut Undang-Undang Nomor 20 Tahun 2008 tentang Usaha Mikro, Kecil, dan Menengah, yaitu bertujuan menumbuhkan dan mengembangkan usahanya dalam rangka membangun perekonomian nasional berdasarkan demokrasi ekonomi yang berkeadilan. Disamping itu tingkat penciptaan lapangan kerja lebih tinggi pada usaha mikro dari pada yang terjadi di perusahaan besar (Sutrisno dan Sri, 2006). Usaha Kecil di Kelurahan Genuksari Kecamatan Genuk berjumlah 42 usaha kecil.

Salah satu tolok ukur berkembangnya usaha adalah adanya akuntansi khususnya pembukuan terkait kas yang benar dan diiringi dengan peningkatan omset.

Menurut Soemarso (2004), akuntansi keuangan (financial accounting) merupakan bidang akuntansi yang berhubungan dengan penyusunan laporan keuangan secara berkala untuk suatu unit ekonomi secara keseluruhan kepada pihak-pihak diluar perusahaan. Laporan keuangan adalah beberapa lembar kertas dengan angka-angka yang tertulis diatasnya tetapi penting juga untuk memikirkan aset-aset nyata yang berada dibalik angka tersebut. Menurut Munawir (2004) menyatakan bahwa laporan keuangan merupakan produk proses laporan keuangan yang diatur oleh standar dan aturan akuntansi, insentif manajer, serta mekanisme pelaksanaan dan pengawasan perusahaan. Pemahaman mengenai lingkungan pelaporan keuangan perlu disertai pemahaman tujuan dan konsep yang mendasari informasi akuntansi yang disajikan dalam laporan keuangan. Pengetahuan ini akan membantu dalam melihat posisi keuangan yang sesungguhnya dan kinerja perusahaan dengan lebih baik. Di sisi lain, Fahmi (2011) mengatakan laporan keuangan merupakan suatu informasi yang menggambarkan kondisi suatu perusahaan, dimana selanjutnya itu akan menjadi suatu informasi yang menggambarkan tentang kinerja suatu perusahaan. Menurut Prastowo dan Yulianti (2005), pihak-pihak yang berkepentingan menggunakan laporan keuangan sebagai salah satu informasi untuk membuat keputusan ekonomi adalah: (1) Investor, bagi investor potensial akan melihat kemungkinan potensi keuntungan yang diperoleh dari perusahaan yang dilaporkan. (2) Pemegang Saham, ingin mengetahui kondisi keuangan perusahaan, aset, utang, modal, hasil, biaya, dan laba. (3) Manajer, ingin mengetahui situasi ekonomis perusahaan yang dipimpinnya. (4) Karyawan, menggunakan informasi dalam laporan keuangan untuk menilai kemampuan perusahaan dalam memberi gaji, upah, pensiun dan balas jasa lainnya. (5) Kreditor, untuk menilai kelayakan perusahaan untuk menerima kredit yang akan diluncurkan. (6) Analisis Pasar modal, ingin mengetahui nilai perusahaan, kekuatan dan posisi keuangan perusahaan. (7) Instansi Pajak, menggunakan laporan keuangan sebagai dasar menentukan kebenaran perhitungan pajak, pembayaran pajak, pemotongan pajak, restitusi dan juga untuk dasar penindakan. (8) Langganan / Lembaga 
Konsumen, untuk melindungi diri dari kemungkinan praktik yang merugikan. (9) Lembaga Swadaya Masyarakat, untuk menilai sejauh mana perusahaan merugikan pihak tertentu yang dilindunginya. (10) Pemerintah, ingin mengetahui apakah perusahaan telah mengikuti peraturan yang telah ditetapkan. (11) Akademis, laporan keuangan menjadi bahan dasar yang diolah untuk mengambil kesimpulan dari suatu hipotesis / penelitian yang dilakukan.

Tujuan laporan keuangan berdasarkan Standar Akuntansi Keuangan per 1 Juli 2009 adalah menyediakan informasi yang menyangkut posisi keuangan, kinerja, serta perubahan posisi keuangan suatu perusahaan yang bermanfaat bagi sejumlah besar pengguna dalam pengambilan keputusan ekonomi.

Akuntansi berkaitan dengan cara usaha mengkomunikasikan informasi akuntansi kepada publik yang terdiri dari berbagai pihak yang melakukan keputusan investasi, meminjam uang atau yang melakukan bisnis dengan perusahaan. Menurut Fahmi (2011) "kas adalah aset keuangan yang digunakan untuk kegiatan operasional perusahaan. Kas merupakan aset yang paling liquid karena dapat digunakan untuk membayar kewajiban perusahaan. kas merupakan alat pembayaran yang siap dan bebas dipergunakan untuk membiayai kegiatan entitas". Sedangkan menurut Munawir (2004) "kas adalah asset lancar yang terdiri dari uang logam, uang kertas, dan unsur-unsur lain yang (1) berfungsi sebagai alat pertukaran dan (2) memberikan dasar untuk perhitungan akuntansi.

Pembukuan dalam perusahaan bisnis adalah dasar dari sistem akuntansi. Menurut UU Nomor 28 Tahun 2007 Pasal 28, pembukuan adalah suatu proses pencatatan yang dilakukan secara teratur untuk mengumpulkan data dan informasi keuangan yang meliputi harta, kewajiban, modal, penghasilan, dan biaya, serta jumlah harga perolehan dan penyerahan barang atau jasa, yang ditutup dengan menyusun laporan keuangan berupa neraca, dan laporan laba rugi untuk periode tahun pajak tersebut. Terdapat beberapa metode umum dalam pembukuan yaitu sistem pembukuan masukan-tunggal dan pembukuan berpasangan. Kedua sistem ini dapat dilihat sebagai pembukuan nyata. Sistem pembukuan masukan-tunggal adalah sumber catatan pembukuan primer seperti buku kas.

Hal ini sama dengan daftar rekening koran dan menempatkan pendapatan dan pengeluaran ke berbagai akun pendapatan dan pengeluaran. Sistem ini bekerja hanya jika Anda bergerak dalam perusahaan kecil dengan volume transaksi yang rendah. Sedangkan Sistem Berpasangan cocok untuk perusahaan berukuran besar dan memiliki kompleksitas. Dengan sistem ini, Anda dapat membuat dua entri untuk setiap transaksi. Debit dibuat ke satu akun dan sebuah kredit dibuat ke akun lainnya. Ini adalah kunci dari sistem berpasangan. Bentuk pembukuan ini lebih baik daripada pembukuan masukan-tunggal.

Pembukuan kas pelaku usaha kecil telur asin di Kelurahan Genuksari Kecamatan genuk Kota Semarang ternyata belum ada bahkan tidak dilakukan pembukuan usaha sama sekali. Oleh karena itu, peningkatan pengetahuan pembukuan melalui edukasi akuntansi khususnya pembukuan kas usaha kepada para pelaku usaha kecil telur asin sangat perlu dilaksanakan. Peningkatan pengetahuan pembukuan kas melalui edukasi ini dilakukan melalui berbagai cara, diantaranya melalui edukasi berupa penyuluhan. Meskipun telah sering dilakukan upaya pengembangan usaha di Kelurahan Genuksari ini namun ternyata masih ditemui kendala-kendala di atas. Dalam hal mengatasi kendala-kendala tersebut maka dbutuhkan edukasi penyuluhan akuntansi khususnya pembukuan kas usaha kepada pelaku usaha kecil telur asin agar usahanya meningkat.

\section{Tujuan dan Manfaat Kegiatan}

Pelaksanaan kegiatan PKM ini bertujuan untuk memberikan edukasi berupa penyuluhan pembukuan kas kepada pelaku usaha kecil telur asin di Kelurahan Genuksari Kecamatan Genuk. Adapun manfaat kegiatan PKM adalah dapat membantu pelaku usaha kecil telur asin di Kelurahan Genuksari Kecamatan Genuk dalam mengelola kas-nya yang sangat bermanfaat bagi kemajuan usaha, dimana awalnya pelaku usaha kecil telur asin di Kelurahan Genuksari Kecamatan Genuk belum dapat memisahkan antara kekayaan pribadi pelaku usaha kecil telur asin sebagai pemilik (rumah tangga) dengan asset usaha yang akhirnya berdampak kerancuan data keuangan (kas-nya).

\section{METODE PELAKSANAAN}

Sasaran kegiatan PKM yaitu pelaku usaha 
kecil telur asin di Kelurahan Genuksari Kecamatan Genuk. Metode kegiatan PKM ini adalah :

1. Memberikan edukasi berupa penyuluhan kepada pelaku usaha kecil telur asin di Kelurahan Genuksari Kecamatan Genuk, dengan materi penyuluhan: pengertian pembukuan kas dan ruang lingkup pembukuan kas termasuk membuat laporan arus kas-nya

2. Disamping edukasi berupa penyuluhan juga dilakukan contoh kasus transaksi usaha terkait kas.

3. Evaluasi PKM

\section{(a) Evaluasi Awal Usaha UMK}

Kegiatan tahap ini untuk mengevaluasi kegiatan pelaku usaha kecil telur asin di Kelurahan Genuksari Kecamatan Genuk yang telah dilakukan saat ini dan penyelesaian permasalahan yang dijadikan prioritas.

(b) Evaluasi

Pelaksanaan

\section{Penyuluhan}

Tim PKM melakukan kegiatan evaluasi terhadap pelaku usaha kecil telur asin di Kelurahan Genuksari Kecamatan Genuk.

Evaluasi PKM ini dilakukan dengan memberi daftar pertanyaan pre test dan post test atas materi-materi penyuluhan pembukuan kas dari Tim PKM. Indikator keberhasilan kegiatan PKM ini berupa peningkatan pengetahuan pembukuan kas bagi pelaku usaha kecil telur asin di Kelurahan Genuksari Kecamatan Genuk. Bila skor post test peserta UMK lebih tinggi daripada skor pre test-nya, maka kegiatan PKM berupa edukasi melalui penyuluhan pembukua berhasil.

Model jawaban pilihan ganda, dengan memilih satu jawaban yang paling tepat.

Nilai peserta $=($ jumlah jawaban benar $) /$ (jumlah soal) x 100

Evaluasi post test penyuluhan pebmukuan kas ditambah penyelesaian contoh kasus tentang kas dengan cara yang tepat guna untuk membuat pembukua kas.

\section{HASIL DAN PEMBAHASAN}

Edukasi penyuluhan pembukuan kas ini diikuti oleh 29 orang pelaku usaha telur asin yang terdiri: 19 orang perempuan dan 11 orang lakilaki. Mereka berasal dari $6 \mathrm{RT}$ dan $2 \mathrm{RW}$ di lingkungan Kelurahan Genuksari Kecamatan Genuk. Pelaksanaan kegiatan PKM ini diselenggarakan, pada: Minggu, 28 Juli 2019 mulai jam 09.00 - 15.00 WIB di Balai Kelurahan Genuksari Kecamatan Genuk.

Pelaksanaan kegiatan terdiri dua tahap, yaitu: tahap kesatu berupa ceramah penyuluhan pengertian pembukuan kas, jenis-jenis transaksi usaha, bagaimana perubahan kas akibat adanya transaksi usaha, bagaimana melakukan pembukuan kas baik untuk kas masuk maupun kas keluar dan bagaimana membuat laporan arus kasnya. Dilanjutkan dengan tahap kedua berupa contoh kasus transaksi kas. Selama proses pelaksnaan kegiatan PKM para pelaku usaha kecil telur asin sangat antusias termasuk dalam diskusi dan tanya jawab serta studi kasus usaha serta sangat puas mendengarkan para dosen pemateri.

Dalam pelaksanaan kegiatan PKM diterangkan keberadaan kas bagi usaha sangat penting untuk melakukan kegiatan operasi, investasi dan pendanaan untuk mencapai tujuan perusahaan. Kas merupakan akun (perkiraan) yang paling likuid keberadaannya jika dibandingkan dengan akun-akun lainnya dalam neraca perusahaan.

Kas didefinisikan sebagai alat pembayaran yang siap dan bebas dipergunakan untuk membiayai kegiatan umum perusahaan. Untuk lebih jelasnya berikut diuraikan beberapa definisi kas dan setara kas. Kas dan setara kas menurut PSAK No.2 (IAI: 2009) "Kas terdiri dari saldo kas (cash on hand) dan rekening giro. Setara kas (cash equivalent) adalah investasi yang sifatnya sangat liquid, berjangka pendek dan dengan cepat dapat dijadikan sebagai kas dalam jumlah tertentu tanpa menghadapai risiko perubahan nilai yang signifikan".

Kas merupakan komponen aktiva (asset) lancar yang paling likuid di dalam neraca, karena kas sering mengalami mutasi atau perpindahan dan hampir semua transaksi yang terjadi dalam perusahaan akan mempengaruhi posisi kas. 
VIVABIO

Jurnal Pengabdian Multidisiplin

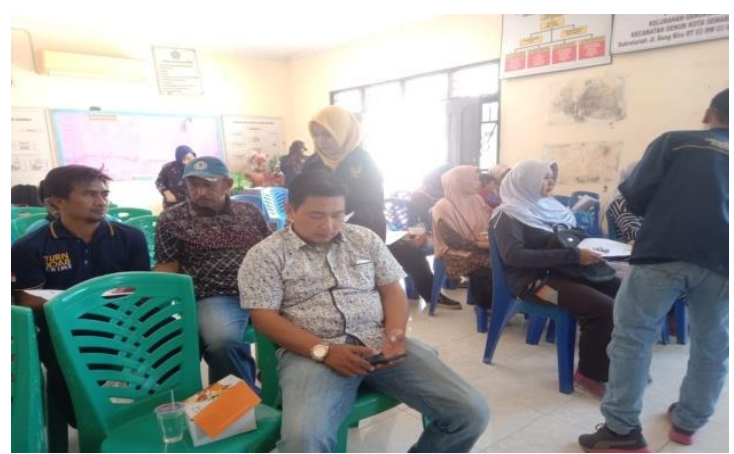

Gambar 1. Pelaksanaan Kegiatan edukasi pembukuan kas

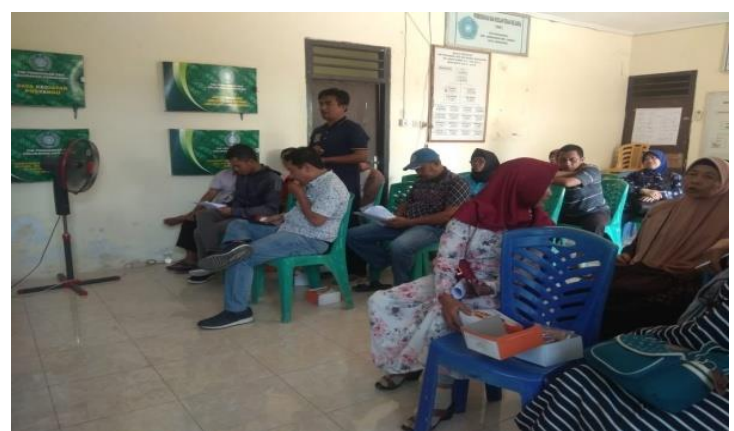

Gambar 2. Proses diskusi dan tanya jawab tentang pembukuan kas

Dalam Standar Akuntansi Keuangan (IAI, 2009), Aset lancar dijelaskan bahwa suatu aset diklasifikasikan sebagai aset lancar jika aset tersebut:

1. Diperkirakan akan direalisasikan atau dimiliki untuk dijual atau digunakan dalam jangka waktu siklus operasi normal perusahaaan

2. Dimiliki untuk diperdagangkan atau untuk tujuan jangka pendek dan diharapkan kan direalisasikan dalam jangka waktu 12 (dua belas) bulan dari tanggal neraca

3. Berupa kas atau setara kas yang penggunaannya tidak dibatasi

Dari definisi kas dan setara dapat disimpulkan bahwa:

1. Kas dan setara kas bukan hanya yang ada di perusahaan, tetapi juga saldo rekening giro di bank yang penggunaannya tidak dibatasi dan suratsurat berharga yang dapat ditarik dengan segera menjadi kas sehingga risikonya kecil akibat pengaruh terjadinya perubahan nilai dari perubahan tingkat suku bunga.

2. Umumnya kas dan setara digunakan untuk membiayai kegiatan umum perusahaan, sehingga kas dan setara kas secara langsung atau tidak langsung hampir mempengaruhi semua transaksi bisnis perusahaan.

3. Perkiraan kas dan setara kas di Neraca disajikan pada urutan pertama golongan aktiva lancar karena merupakan aktiva yang paling likuid.

Manajemen kas yang efisien membutuhkan kas yang tersedia untuk operasional atau dalam investasi jangka pendek dan jangka panjang.

Oleh karena itu, manajemen kas adalah fungsi bisnis kritis. Salah satu tanggung jawab manajer keuangan perusahaan adalah mengatur sumbersumber kas untuk memastikan tersedianya kas untuk kebutuhan jangka pendek juga merencanakan kebutuhan kas jangka panjang untuk memperlancar kebutuhan dan perkembangan perusahaan

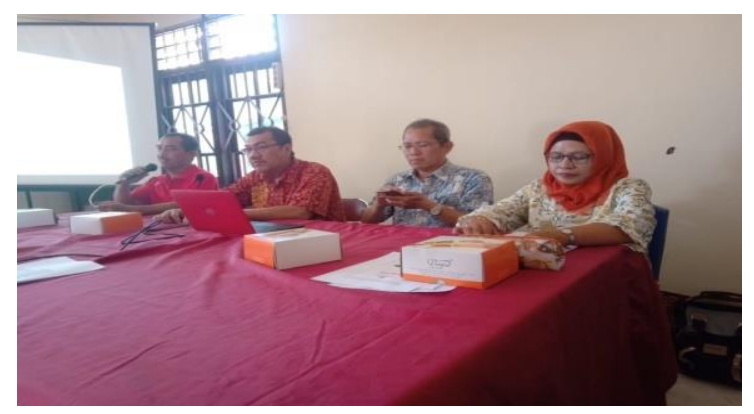

Gambar 3. Dosen pemateri menyampaikan edukasi tentang pembukuan kas

Adapun hasil evaluasi kegiatan PKM tahap awal terhadap pelaku usaha kecil telur asin di Kelurahan Genuksari Kecamatan Genuk adalah ternyata dalam menjalankan usahanya yang dilakukan saat ini masih berdasarkan apa adanya.

Pembukuan usaha terutama dalam hal pembukuan kas belum dilakukan dengan sistematis sehingga tidak diketahui perkembangan usahanya. Dengan demikian kegagalan masih sering dialami pelaku usaha kecil telur asin di Kelurahan Genuksari Kecamatan Genuk sehingga berakibat usahanya belum optimal.

Evaluasi: Sebelum dan sesudah penyuluhan, seluruh peserta diberi daftar pertanyaan untuk mengetahui:

- Tingkat pemahamannya tentang kas 
dihadapinya, yaitu belum adanya pembuatan

secara benar,

- Besarnya minat untuk melakukan pembukuan kas.

Model jawaban pilihan ganda, dengan memilih satu jawaban yang paling tepat.

Nilai peserta $=($ jumlah jawaban benar $) /$ (jumlah soal) x 100

Jawaban untuk pertanyaan minat adalah berminat, abstain, tidak berminat. Keberhasilan edukasi penyuluhan ditetapkan:

- Dari nilai jawaban soal tingkat pemahaman: Adanya peningkatan nilai peserta antara pre dan post test. Nilai post test $\geq 60$.

- Dari nilai jawaban soal minat: $\geq 60 \%$ peserta berminat

- Dari hasil test tersebut, dinyatakan berhasil karena sudah sesuai dengan standart keberhasilan, yakni:

- Dari nilai jawaban soal tingkat pemahaman: Adanya peningkatan nilai peserta antara pre dan post test yakni dari $72 \%$ menjadi $90 \%$ dan nilai post test $\geq 60$.

- Dari nilai jawaban soal minat, baik pre test maupun post test hasilnya $\geq 60 \%$ peserta berminat, yakni $79 \%$ kemudian meningkat menjadi $93 \%$.

Secara umum pelaku usaha kecil telur asin di Kelurahan Genuksari Kecamatan Genuk sebagai mitra PKM ternyata antusias mengikuti semua penjelasan dari Tim dosen pemateri PKM yang bekerjasama dengan Lembaga Penelitian dan Pengabdian kepada Masyarakat (LPPM) USM.

\section{KESIMPULAN DAN SARAN}

\section{Kesimpulan}

1. Dalam menjalankan usahanya selama ini pelaku usaha kecil telur asin ternyata masih ada permasalahan yang pembukuan usaha khususnya pembukuan kas.

2. Metode PKM adalah edukasi berupa penyuluhan pembukuan kas kepada pelaku usaha kecil telur asin di Kelurahan Genuksari Kecamatan Genuk.

3. Capaian kegiatan PKM atas pelaksanaan edukasi pembukan kas adalah telah disusunnya pembukuan kas yang dapat menghasilkan informasi keuangan berupa laporan arus kas.

4. Pelaku usaha kecil telur asin di Kelurahan Genuksari Kecamatan Genuk sebagai mitra PKM ternyata antusias mengikutinya.

\section{Saran}

Pelaku usaha kecil telur asin diharapkan dapat menyebarkan pengetahuan yang diperoleh selama edukasi (penyuluhan pembukuan kas) kepada pelaku usaha kecil lainnya dilingkungannya yang tidak bisa mengikuti PKM ini.

\section{UCAPAN TERIMA KASIH}

Ucapan terima kasih dari Tim PKM kepada Lembaga Penelitian dan Pengabdian kepada Masyarakat Universitas Semarang (LPPM-USM) yang sudah mendanai pelaksnaan kegiatan PKM ini pada tahun 2019.

Terima kasih juga Tim PKM sampaikan kepada pelaku usaha kecil telur asin di Kelurahan Genuksari Kecamatan Genuk Kota Semarang yang sudah dengan sukarela menerima TIM PKM untuk melaksanakan dan memberikan edukasi berupa kegiatan penyuluhan pembukuan kas usaha.

\section{REFERENSI}

BPS, 2019. Kecamatan Genuk Dalam Angka. Semarang

Dwi Prastowo dan Rifka Julianti. 2005. Analisis Laporan Keuangan. Konsep dan Aplikasi. Edisi Kedua. UPP AMP YKPN, Yogyakarta 
Fahmi, Irham. 2011. Analisis Laporan Keuangan. Lampulo: ALFA BETA. Jakarta

Ikatan Akuntan Indonesia. 2009. Eksposure Draft Pernyataan Standar Akuntansi Keuangan: Penyajian Laporan Keuangan.

Januarsi, Yeni. 2011. PSAK NO. 1 (Revisi 2009) Komponen Laporan Keuangan Lengkap, Penyajian Laporan Keuangan, dan Extraordinary items. Buletin Akuntan Muda. Edisi Juni 2011. Jakarta

Munawir, 2004. Analisa Laporan Keuangan, Edisi Keempat, Cetakan Ketiga belas, Liberty. Yogyakarta

Neddy, Rafinaldy, 2006. Memeta Potensi Dan Karakteristik UMKM Bagi Pertumbuhan Usaha Baru, Infokop Nomor .29.

Sutrisno, Joko dan Sri Lestari, 2006. Kajian Usaha Mikro Indonesia. Jurnal Pengkajian Koperasi dan UKM Nomor 2 Tahun I-2006

Undang-Undang Republik Indonesia Nomor 20 Tahun 2008 tentang Usaha Mikro, Kecil dan Menengah

Wild, Jhon. J, K. R. Subramanyam, 2010, Analisis Laporan Keuangan, Salemba Empat, Jakarta 